Research Article

\title{
Stress Corrosion Behavior of Ungrouted Pretensioned Concrete Beams
}

\author{
Velu Saraswathy, ${ }^{1,2}$ Han-Seung Lee, ${ }^{2}$ Subbiah Karthick, ${ }^{2}$ and Seung-Jun Kwon ${ }^{3}{ }^{3}$ \\ ${ }^{1}$ Corrosion and Materials Protection Division, CSIR-Central Electrochemical Research Institute, Karaikudi 630003, \\ Tamil Nadu, India \\ ${ }^{2}$ Department of Architectural Engineering, Hanyang University, Erica Campus, Sangrok-gu, Ansan, Gyeonggi-do 15588, \\ Republic of Korea \\ ${ }^{3}$ Department of Civil Engineering, Hannam University, Daejeon 34430, Republic of Korea
}

Correspondence should be addressed to Seung-Jun Kwon; jjuni98@hannam.ac.kr

Received 18 September 2017; Revised 7 November 2017; Accepted 27 November 2017; Published 21 January 2018

Academic Editor: Michael J. Schütze

Copyright ( 2018 Velu Saraswathy et al. This is an open access article distributed under the Creative Commons Attribution License, which permits unrestricted use, distribution, and reproduction in any medium, provided the original work is properly cited.

Prestressed concrete beams of size $150 \times 150 \times 1000 \mathrm{~mm}$ were designed, and two bonded cold-drawn $7 \mathrm{~mm}$ steel wires were stressed at $70 \%$ UTS under service conditions before concreting. The beams were cast with M40 grade concrete mix with various percentages of chlorides ranging from $0,1,2$, and $3 \%$ by weight of cement and cured for 28 days. After 28 days, the stretching forces were released, the prestressing steel wire was allowed to regain its original length, the tensile stresses were transformed into a compressive stress in the concrete, and the stress corrosion behavior was assessed. Stress corrosion cracking (SCC) is due to the simultaneous action of stress, corrosive media, and material properties. The stress corrosion behavior of ungrouted pretensioned steel was assessed by using various electrochemical techniques such as electrochemical noise, open-circuit potential measurement, AC impedance, and potentiodynamic polarization measurements. The same experiments were conducted for rebars embedded in the concrete beam with various percentages of chlorides ranging from $0,1,2$, and $3 \%$ by weight of chloride. After 30 days of exposure, the beams were tested for their flexural strength measurements to find out the load-bearing capacity.

\section{Introduction}

Prestressed concrete (PC) structures are commonly used for long-span bridges, dams, silos and tanks, industrial pavements, and nuclear containment structures [1]. Compressive stresses are induced in prestressed concrete either by pretensioning or posttensioning. In pretensioning, the steel is stretched before concreting. Pretensioned concrete is used in precast members such as roof slabs, piles, poles, bridge girders, wall panels, and railroad ties. In posttensioning, the steel is stretched after the concrete hardens [2]. Posttensioned concrete is used for bridges, large girders, floor slabs, shells, roofs, and pavements. PC is used in school auditoriums, gymnasiums, and cafeterias because of its acoustical properties and its ability to provide long, open spaces. One of the most widespread uses of PC is parking garages [3]. PC has high ability to resist the impact, high fatigue resistance, and high live load-carrying capacity and is highly crack resistant.
The PC structures have smaller deformation and can absorb more tension than the nonprestressed concrete structure [4]. PC structures are usually constructed by using highperformance concrete containing high-strength steel under very high levels of tensile load. The damage due to microcracking leads to a loss of elastic modulus. And the presence or ingress of chloride ions may cause the corrosion of steel wires which will lead to sudden or brittle failure of steel wires causing premature failure of concrete structures [5-9].

High-strength steel is susceptible to stress corrosion cracking, hydrogen embrittlement, or a combination of both mechanisms called hydrogen-induced stress corrosion cracking in the presence of aggressive environments. And SCC is caused due to the combined effect of mechanical loading, aggressive environment and some defects in the material [10-13]. The defects present in the steel wires are the weaker spots from which corrosion initiates, and they act as a stress concentrated area where diffusion of hydrogen 


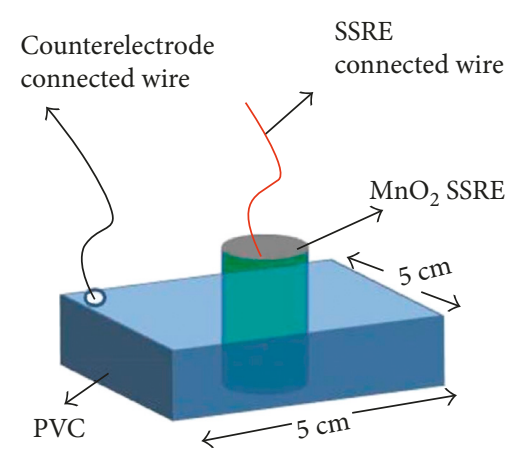

(a)

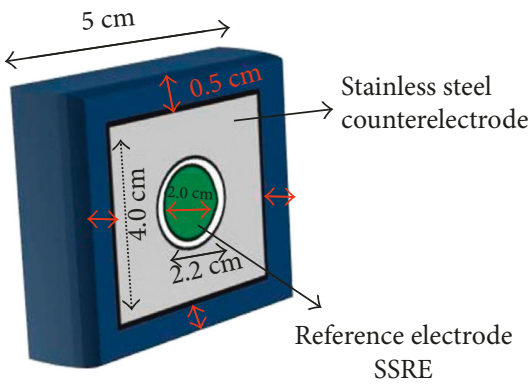

(b)

FIgURE 1: Schematic diagram of the ECMP [17]. (a) Top view. (b) Side view.

TABLe 1: Chemical composition of OPC.

\begin{tabular}{lccccccc}
\hline Compound & $\mathrm{SiO}_{2}$ & $\mathrm{Al}_{2} \mathrm{O}_{3}$ & $\mathrm{Fe}_{2} \mathrm{O}_{3}$ & $\mathrm{CaO}$ & $\mathrm{MgO}$ & $\mathrm{SO}_{3}$ & $\mathrm{LOI}$ \\
\hline Wt.\% & $20-21$ & $5.2-5.6$ & $4.4-4.8$ & $62-63$ & $0.5-0.7$ & $2.4-2.8$ & $1.5-2.5$ \\
\hline
\end{tabular}

TABLE 2: Chemical composition of alloying elements of the prestressing steel.

\begin{tabular}{lcccccccccc}
\hline Composition & $\mathrm{C}$ & $\mathrm{Mn}$ & $\mathrm{Si}$ & $\mathrm{P}$ & $\mathrm{S}$ & $\mathrm{Cr}$ & $\mathrm{Cu}$ & $\mathrm{Ni}$ & $\mathrm{Ti}$ & $\mathrm{Al}$ \\
\hline Wt.\% & 0.82 & 0.74 & 0.21 & 0.12 & 0.008 & 0.17 & 0.09 & 0.03 & 0.03 & 0.03 \\
\hline
\end{tabular}

contributes towards the SCC damage process [14, 15]. Pitting corrosion is considered as a significant cause of brittle failure of prestressed concrete structures [16, 17]. Pitting corrosion reduces the cross-sectional area of the prestressing steel and hence the load-carrying capacity of the structure [18]. The reported failures due to SCC are the collapse of the Berlin Congress Hall [19], accident at the Uster indoor swimming pool in Switzerland, collapse of a railway overpass at Berghausen, Germany [20], and collapse of the Bickton Meadows bridge, the Ynys-Y-Gwas bridge in UK [21], and the Saint Stefano bridge in Italy [22]. Many researchers have studied the corrosion behavior of PC structures [23-25]. Studies revealed that strand corrosion decreases the ultimate strength and the ductility of pretensioned members $[26,27]$. Strand corrosion will affect the structural stability in terms of prestress loss, strength degradation, structural cracking, and failure of structures [28-32]. The effect of strand corrosion on structural behavior was studied by many researchers [33-35]. Li et al. [36] reported that the combined effect of fatigue and corrosion behavior decreased the bond with increased fatigue stress under a constant action of corrosion. It was reported that the corrosion of the strand in the pretensioned PC structure was found to degrade the tensile strength of the strand instead of its bond strength [37]. It has been found that the stress corrosion is more dominant than pitting corrosion [18]. Pits may be an initiation site for SCC or hydrogen embrittlement (HE) $[5,6]$.

In the present investigation, prestressed concrete beams of size $150 \times 150 \times 1000 \mathrm{~mm}$ were cast with two pretensioned steel wires and M40 grade concrete with $1 \%, 2 \%$, and $3 \%$ chloride by weight of cement. The stress corrosion behavior of ungrouted pretensioned steel wires was assessed by using various electrochemical techniques such as open-circuit potential, AC impedance, linear polarization, Tafel extrapolation, noise measurements, and weight loss measurements. All these measurements were made by using the fabricated embedded corrosion rate monitoring probe (ECMP). The sensor was fabricated as per the procedure reported elsewhere [38]. The schematic representation of the ECMP used for the investigation is given in Figure 1 [39]. The experiments were carried out for the rebars embedded in the concrete beam, and the results are discussed in detail.

\section{Experimental}

2.1. Materials Used in the Test. Ordinary Portland Cement 43 grade as per the Indian standard (IS) 8112 was used for the investigation. The specific gravity of the cement used was 3.14. The properties of OPC are shown in Table 1. Natural river sand of size below $4.75 \mathrm{~mm}$ conforming to zone III of IS 383-1970 was used as fine aggregates. Coarse aggregates used in this study consist of crushed stone of size $12 \mathrm{~mm}$ and below. The specific gravity of the fine and coarse aggregates used was 2.64 and 2.63. Cold-drawn stress-relieved prestressing plain steel wire of $7 \mathrm{~mm}$ diameter having an ultimate tensile strength of $1470 \mathrm{~N} / \mathrm{mm}^{2}$ conforming to IS 1785, Part 1, was used for the study. The chemical composition of the prestressing steel used was given in Table 2. AR (analytical grade) $\mathrm{NaCl}$ purchased from Fischer Scientific was used for the investigation. 


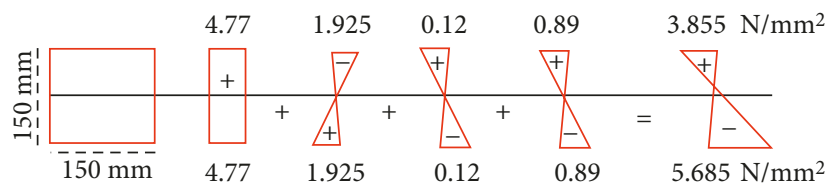

Figure 2: Resultant stress in concrete.

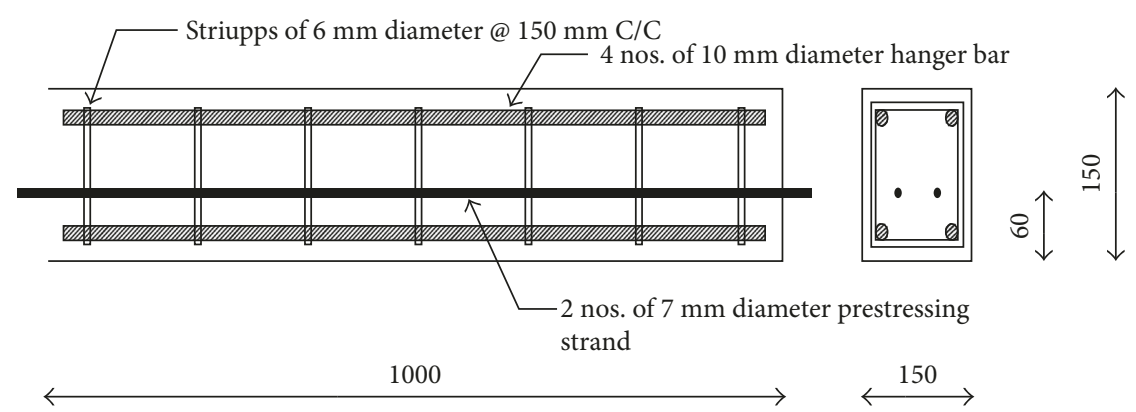

Figure 3: Schematic diagram of prestressing concrete specimen details.

\subsection{Material Properties}

Nominal diameter of the prestressing steel $=7 \mathrm{~mm}$

Ultimate tensile stress of the prestressing steel $(\mathrm{fpk})=$ $1470 \mathrm{~N} / \mathrm{mm}^{2}$

Cube compressive strength $(\mathrm{fck})=40 \mathrm{~N} / \mathrm{mm}^{2}$

Mix ratio used (mass by weight) $=1: 0.98: 2.96: 0.4$

Cement : FA : CA : water $\left(\mathrm{kg} / \mathrm{m}^{3}\right)=450: 444: 1333: 180$

Thermomechanically treated (TMT) rebar $=12 \mathrm{~mm}$ diameter, 450 grade

Size of the beam $(b \times d \times l)=150 \times 150 \times 1000 \mathrm{~mm}$

Cross-sectional area of the beam $=22,500 \mathrm{~mm}^{2}$

Area of the steel wire (Aps) $=38.2 \mathrm{~mm}^{2}$

Eccentricity from the center $(e)=10 \mathrm{~mm}$

Prestressing force $(P)=107.8 \mathrm{kN}$

\subsection{Casting Procedure}

2.3.1. Pretensioning of Strands, Casting, and Curing Procedure. In general, there are two ways in which prestressing of concrete by steel elements can be accomplished, namely, pretensioning and posttensioning. In pretensioning, the strands are tensioned before the casting of the concrete, and in posttensioning, the strands are tensioned after the concrete hardens enough to support the stress. In this work, the pretensioning technique was adopted.

The prestressed concrete beam of size $150 \times 150 \times 1000 \mathrm{~mm}$ was designed, and two bonded steel wires of $7 \mathrm{~mm}$ diameter were stressed at 70\% UTS (ultimate tensile strength) under service conditions before concreting. The ultimate tensile strength of the $7 \mathrm{~mm}$ steel wire was $1470 \mathrm{~N} / \mathrm{mm}^{2}$. The average yield strength of the $10 \mathrm{~mm}$ TMT steel rebar was $454 \mathrm{~N} / \mathrm{mm}^{2}$ and $6 \mathrm{~mm}$ stirrup was $210 \mathrm{~N} / \mathrm{mm}^{2}$. The elastic modulus of the prestressing steel wire and the TMT rebar was $210 \mathrm{kN} / \mathrm{mm}^{2}$ and $200 \mathrm{kN} / \mathrm{mm}^{2}$, respectively. The resultant stress diagram is given in Figure 2. The beams are reinforced with two $10 \mathrm{~mm}$ diameter rebars at the bottom, two $12 \mathrm{~mm}$ diameter rebars at the top, and $6 \mathrm{~mm}$ stirrups at $150 \mathrm{~mm}$ spacing. ECMP was embedded very near to the pretensioned steel. The schematic of the reinforcement concrete details is given in Figure 3. The beams were cast with M40 grade concrete mix of $1: 0.98: 2.96$ with $0.4 \mathrm{w} / \mathrm{c}$ ratio. While casting, the concrete mix was admixed with $1 \%$, $2 \%$, and $3 \%$ by weight of cement of $\mathrm{NaCl}$ to accelerate the corrosion process. The cast specimens were allowed to remain in the steel mould for 24 hours at room temperature. After $24 \mathrm{hrs}$, the specimens were demolded with care so that no edges were broken and were subjected to cure for 28 days by covering with the wet sack. For each system, triplicate beams were cast. After 28 days of curing, the beams were subjected to corrosion over the period of 30 days, the stress was released, and the measurements were made. At the end of 30 days, the prestressed steel wire and the rebar embedded in the concrete beams were subjected to electrochemical noise, AC impedance, and potentiodynamic polarization measurements. But the open-circuit potential measurements were made after the curing period was over until the end of the 30 th day.

2.3.2. Flexure Test. The prestressed beams were subjected to the flexural test to find out the load-bearing capacity. After 28 days of curing, the beams were allowed to corrode over a period of 30 days, and the stress was released. After that, the beams were dried in the open atmosphere for 24 hours and subjected to the flexural testing in the UTM (universal testing machine) of $100 \mathrm{~T}$ capacity under two-point loading, and the load versus deflection curve and the initial crack load versus final crack load were recorded. The experimental 
setup is shown in Figure 4. Modulus of rupture $\left(F_{b}\right)$ was calculated using the formula:

$$
F_{b}=\frac{3 P L}{2 b d^{2}}
$$

where $P$ is the maximum load at failure, $L$ is the span length of the beam, $b$ is the breadth of the beam, and $d$ is the depth of the beam.

\subsection{Electrochemical Studies}

2.4.1. Electrochemical Noise (ECN). The ECN is one of the nondestructive and nonintrusive techniques being used in monitoring the corrosion process of various metallic materials [40], and it can provide information about the corrosion mechanism [41]. It was found that the sensitivity of the ECN is much higher than that of the other techniques in identifying the localized corrosion process [42]. The ECN is achieved by simultaneous measurement of fluctuation of current and potential caused by the spontaneous electrochemical reactions [43]. The technique of measuring the electrochemical noise uses no applied external signal for the collection of experimental data.

The ECN technique measures the signal perturbations with low-level fluctuations of the corrosion potential between two nominally identical electrodes which can be used in the automatic determination of corrosion type and speed. The noise corresponds with the low-level frequency noise (differential of the ZRA) signal but has much lower amplitude when general corrosion is involved [44]. The technique is widely used within the corrosion engineering as a useful corrosion monitoring technique. ECN measurements were carried out for the prestressed steel and embedded rebars in the chloride-contaminated concrete.

2.4.2. Open-Circuit Potential Measurements. After 28 days of curing, the prestressing steel under stressed conditions and rebars embedded in the concrete beams with and without various percentages of chloride were subjected to open-circuit potential measurements with respect to ECMP. The positive terminal of the microammeter was connected to the prestressing steel and the negative terminal to the ECMP, and the potential versus time plot was plotted for the prestressed steel and rebars. Potential measurements were taken for a period of 30 days.

2.4.3. AC Impedance Spectroscopy. An electrochemical impedance measurement is an appropriate method for corrosion studies, particularly for corrosion rate determinations, passivation, and passivity process and for the evaluation of different inhibitors. Here, the prestressing steel acts as a working electrode, and the stainless steel and ECMP act as a counterelectode and a reference electrode, respectively. Impedance measurements were carried out for the prestressed steel and rebars embedded in the chloridecontaminated concrete. A time interval of 10 to 15 min was given for the OCP to reach a steady state value. The impedance spectroscopy measurement was carried out by using

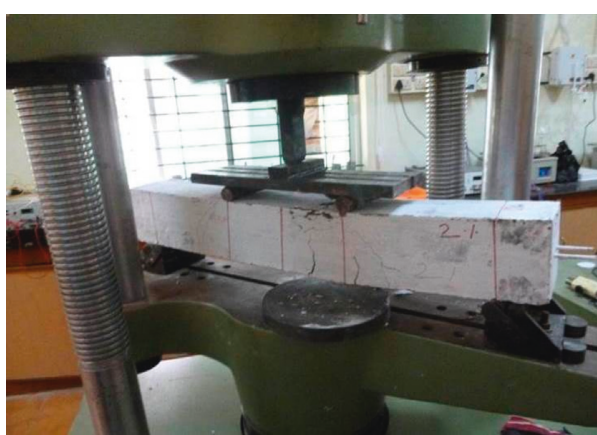

FIgURE 4: Flexural test experimental setup.

ACM Instruments, UK. The real part $\left(Z^{\prime}\right)$ and the imaginary part $\left(-Z^{\prime \prime}\right)$ of the cell impedance was measured for various frequencies $\left(30 \mathrm{kHZ}\right.$ to $10 \mathrm{mHz}$ ). Plots $Z^{\prime}$ versus $-Z^{\prime \prime}$ were made. Impedance measurements were carried out at the end of the exposure period of 30 days.

2.4.4. Potentiodynamic Polarization Technique. The same experimental setup used in the AC impedance technique was used here also. The ACM instrument has provisions for programs to evaluate corrosion kinetic parameters such as $I_{\text {corr }}$ and $E_{\text {corr }}$. The potentiodynamic condition corresponds to a potential sweep rate of $0.1 \mathrm{mVs}^{-1}$ and a potential range of +200 to $-200 \mathrm{mV}$ from OCP. Polarization studies were carried out for all the systems. All the experiments were carried out at a room temperature of $30 \pm 2^{\circ} \mathrm{C}$.

\section{Results and Discussion}

\subsection{Electrochemical Studies}

3.1.1. Electrochemical Noise (ECN). The ECN measurement was performed using ACM instruments, UK, at the end of the 30-day exposure period. The two-electrode system was used for taking the measurements. Two identical prestressing steels were used as the working electrode 1 and working electrode 2, and the ECMP was used as the reference electrode. The electrochemical current noise and the potential noise between the coupled working electrodes and the reference electrode were measured simultaneously. ECN records were taken for $1000 \mathrm{~s}$ containing 1000 data points, recorded with a datasampling interval of $1.0 \mathrm{~s}(1 \mathrm{~Hz})$. The current versus time noise and potential versus time noise plots for the rebars and prestressed steel are given in Figures 5 and 6. From Figure 5, it is observed that the potential and current noise exhibit different characteristics during the experimental period. The potential signal is found to have less fluctuation when compared to the current noise signal. Subsequently, the amplitude of fluctuation was found to increase with the increase in chloride content in both the prestressed steel and the rebar. The current signal fluctuation was found to vary between $0.5 \mu \mathrm{A}$ and $5.5 \mu \mathrm{A}$. The potential fluctuation shift was found to be $-190 \mathrm{mV},-290 \mathrm{mV},-375 \mathrm{mV}$, and $-440 \mathrm{mV}$ for $0,1,2$, and $3 \%$ chloride level, respectively, in the rebar embedded in concrete. It indicates that, in the rebars embedded in $3 \%$ chloride only, the corrosion was initiated. 


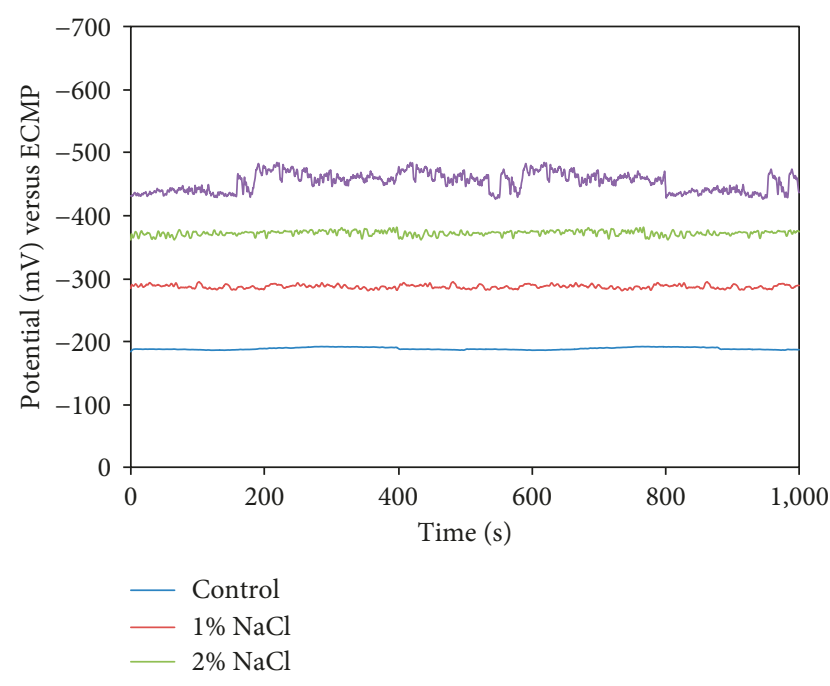

(a)

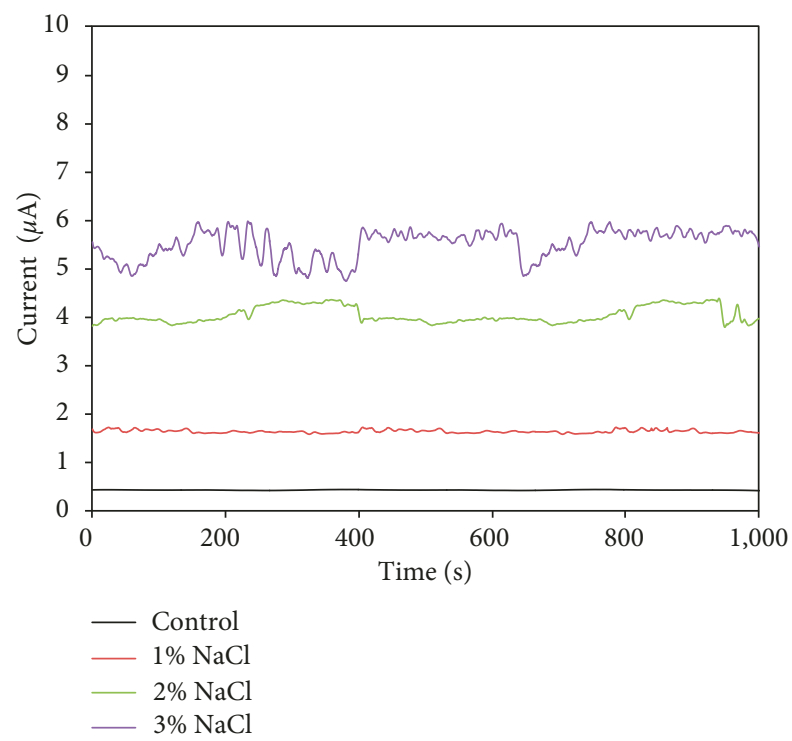

(b)

FIGURE 5: Time records of the potential (a) and current (b) signals for the rebar embedded in chloride-contaminated concrete.

In the case of the prestressed steel (Figure 6), the potential fluctuation was found to be $-175,-280,-410$, and $-510 \mathrm{mV}$, respectively, at $0,1,2$, and $3 \%$, respectively, indicating the active condition of the steel wire at 2 and $3 \%$ chloride levels. The potential noise fluctuation at $3 \%$ chloride was found to be 2.91 times higher than that at $0 \%$ chloride. As the chloride level increases, the potential noise fluctuation was also found to increase. The current fluctuation was varied from $0.50 \mu \mathrm{A}$ to $10.0 \mu \mathrm{A}$. The current noise fluctuation at $3 \%$ chloride level was found to be 20 times higher than that at $0 \%$ chloride level which indicates the severity of the corrosion in the stressed condition. There is a sudden shift observed in both the potential and current noise at 1 to $2 \%$ chloride levels, and from 2 to $3 \%$ chloride, the potential and current noise fluctuation is found to be lesser when compared to 1 to $2 \%$ chloride levels. Zhao et al. [45] observed the

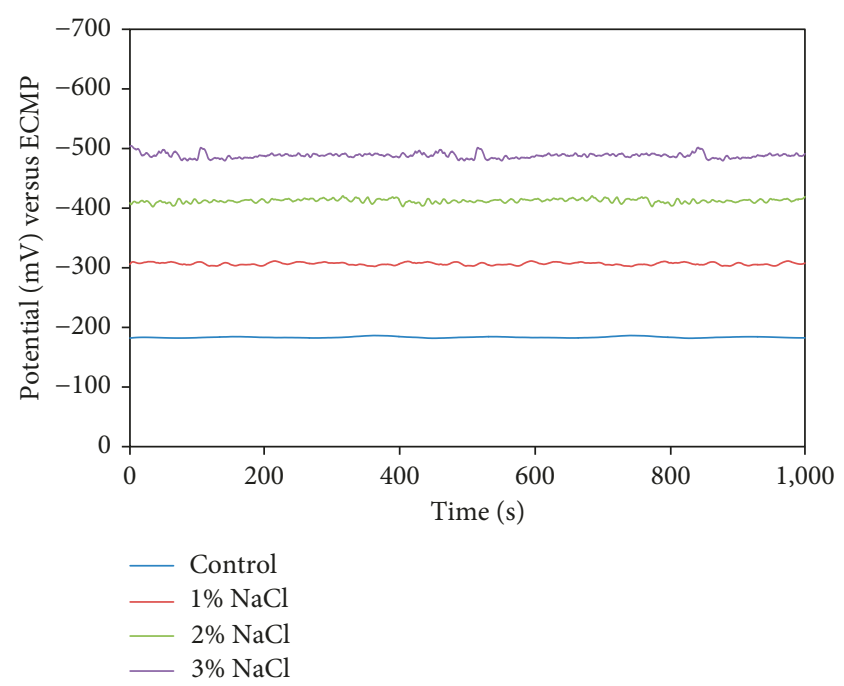

(a)

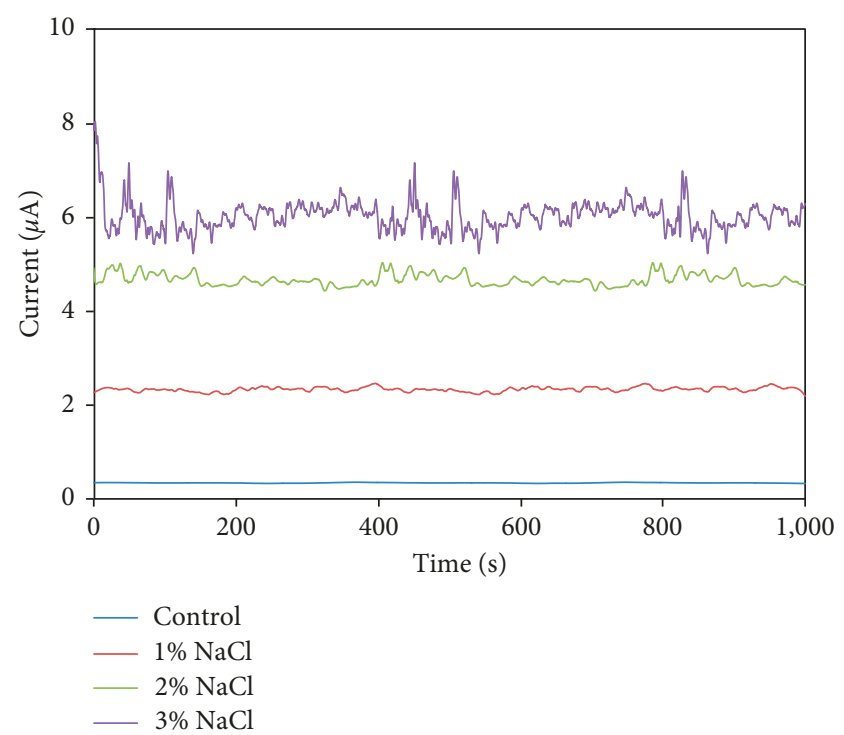

(b)

FIgURE 6: Time records of the potential (a) and current (b) signals for the prestressed steel in chloride-contaminated concrete.

same trend of ECN behavior in chloride-contaminated cement mortar-containing reinforcing steel.

3.1.2. Open-Circuit Potential Measurement. The opencircuit potential measured for the prestressed steel against the ECMP in various chloride concentrations is illustrated in Figure 7. From the figure (Figure 7(a)), it is observed that the potential of the prestressed steel (without chloride) is found to vary between -121 and $-225 \mathrm{mV}$ versus ECMP indicating the passive condition of the steel wire throughout the exposure period of 30 days. However, in $1 \%$ chloridecontaminated concrete, the potential was found to vary between $-242 \mathrm{mV}$ during the starting period and it crossed the threshold limit of $-275 \mathrm{mV}$ after the 4 th day of exposure, and the potential was shifted towards the negative direction 


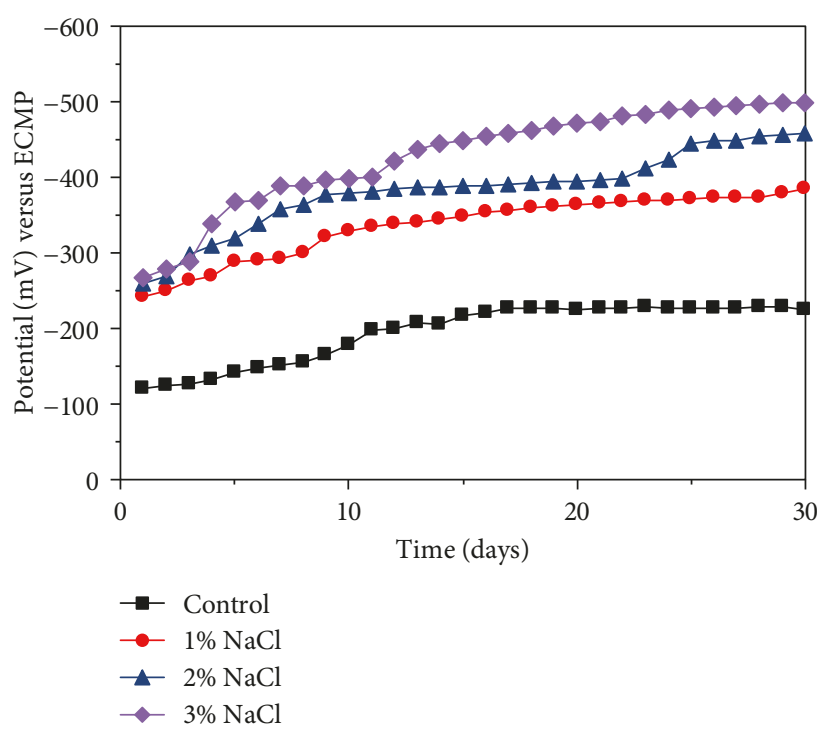

(a)

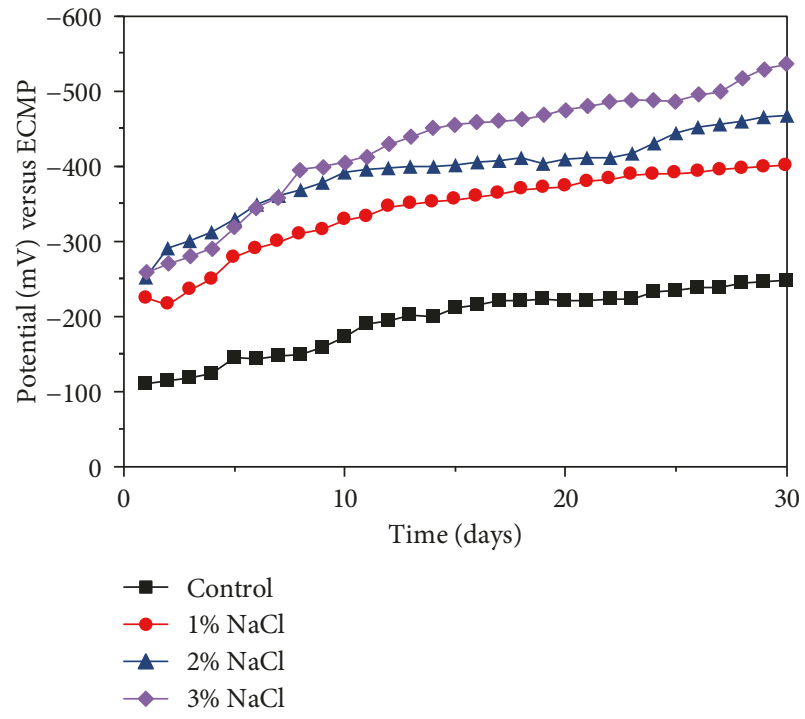

(b)

FIgURE 7: OCP curve for the rebar (a) and prestressed steel (b) in chloride-contaminated concrete.

and it reached $-390 \mathrm{mV}$ at the end of the 30 th day. In $2 \%$ and $3 \%$ chloride-contaminated concrete, the rebar has shown the open-circuit potential of -450 and $-500 \mathrm{mV}$ at the end of the exposure period. The higher shift in potential towards more negative direction indicates the active condition of the rebar. In $3 \%$ chloride, the rebar has shown a more negative potential of $-500 \mathrm{mV}$ versus ECMP at the end of the 30th day indicating the active condition of the rebar.

Figure 7(b) represents the potential versus time plot of the prestressed steel with various chloride levels. From the results, it is found that the prestressed steel in control concrete is under passive condition showing the less negative potential of $-250 \mathrm{mV}$ versus ECMP at the end of 30 days. Whereas in $1 \%, 2 \%$, and $3 \%$ chloride-contaminated concrete, the prestressed steel has shown more negative potentials than the unstressed steel indicating the active nature of the steel after 30 days of exposure. In 3\% chloride, the prestressed steel has shown a more negative potential of $-540 \mathrm{mV}$ versus ECMP after 30 days of the exposure indicating that the tendon has corroded severely.

3.1.3. AC Impedance. The Nyquist plot of the prestressed steel and the rebar embedded in concrete with different $\%$ of chloride levels is given in Figure 8. The parameters obtained from the impedance technique for the prestressed steel and the rebar in various chloride-contaminated concrete after 30 days of exposure are shown in Table 3. From the table, it is found that the stressed steel has shown higher corrosion rate than the unstressed steel in all the chloride levels. After 30 days of exposure in chloride-contaminated concrete, the prestressed steel has 1.06, 1.03, and 1.48 times higher corrosion rate than the rebar embedded in $1 \%, 2 \%$, and $3 \%$ chloride-contaminated concrete. For example, $I_{\text {corr }}$ value for the rebar and the stressed steel in $3 \% \mathrm{NaCl}$ was $1.224 \times 10^{-3} \mathrm{~mA} \cdot \mathrm{cm}^{2}$ and $2.098 \times 10^{-3} \mathrm{~mA} \cdot \mathrm{cm}^{2}$, respectively.
$R_{\mathrm{ct}}$ values of the rebar and prestressed steel in $3 \% \mathrm{NaCl}$ were $2.131 \times 10^{4}$ and $1.441 \times 10^{4} \Omega \cdot \mathrm{cm}^{2}$, respectively. The corrosion rate of the rebar and the prestressed steel in $3 \% \mathrm{NaCl}$ was $1.419 \times 10^{-2}$ mmpy and $2.098 \times 10^{-2} \mathrm{mmpy}$, respectively. In both the prestressed steel and rebar, the $R_{\mathrm{ct}}$ values were found to decrease and $C_{\mathrm{dl}}$ values were found to increase with the increase in chloride concentration, respectively. The $I_{\text {corr }}$ values were found to increase with the chloride concentrations irrespective of the stressed conditions. Compared to the stressed steel, the rebar has lesser corrosion rate, higher $R_{\mathrm{ct}}$ values, and lower $C_{\mathrm{dl}}$ values.

Figure 9 depicts the impedance modulus curve for the rebar and prestressed steel with different percentages of chloride levels after 30 days of exposure. It is found that the impedance values were found to decrease with the increase in chloride concentration. When compared to the prestressed steel, the rebar has lesser impedance values than the prestressed steel in all the chloride levels. In the stressed condition, as the chloride level increases, the impedance value was found to decrease by one order of magnitude at each chloride level. The lowest corrosion resistance of the steel was observed in $3 \% \mathrm{NaCl}$ in both the prestressed steel and the rebar. Slight capacitive behavior with the lowfrequency domain is observed in both the stressed and unstressed steel wires at all chloride levels. These results could be explained by taking into consideration that the chlorides present in the surrounding concrete reached the steel wire and activated/initiated the corrosion process [46].

3.1.4. Potentiodynamic Polarization Studies. The potentiodynamic polarization curve for the rebar and the prestressed steel under various chloride concentration levels is depicted in Figure 10. The corrosion kinetic parameters obtained from the potentiodynamic polarization studies are given in Table 4. From the table, it is observed that the $E_{\text {corr }}$ values of 


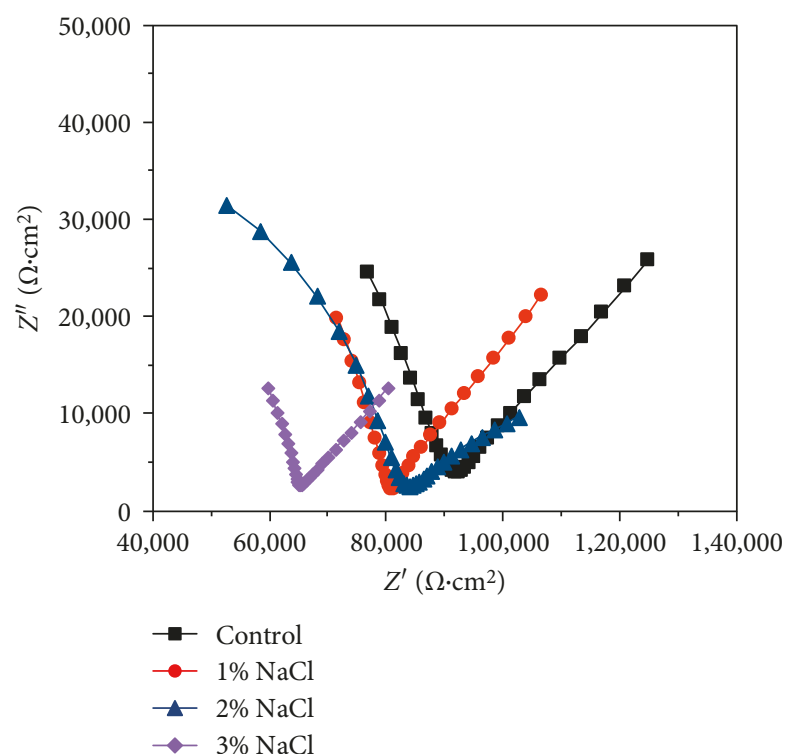

(a)

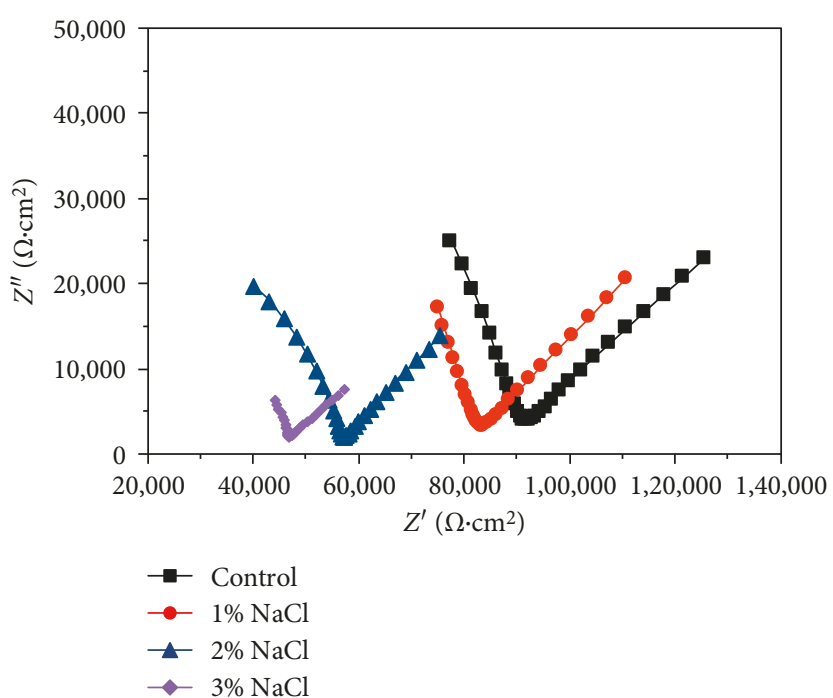

(b)

Figure 8: AC impedance curve for the rebar (a) and prestressed steel (b) in chloride-contaminated concrete.

TABLE 3: Initial and final crack load for the flexural concrete beams.

\begin{tabular}{lccc}
\hline Designation & Initial crack load $(\mathrm{kN})$ & Final crack load $(\mathrm{kN})$ & Modulus of rupture $\left(F_{b}\right)\left(\mathrm{N} / \mathrm{mm}^{2}\right)$ \\
\hline Control & 78 & 120.6 & 5.36 \\
$1 \% \mathrm{NaCl}$ & 76 & 98.5 & 4.38 \\
$2 \% \mathrm{NaCl}$ & 67 & 90.6 & 4.03 \\
$3 \% \mathrm{NaCl}$ & 64 & 80.9 & 3.60 \\
\hline
\end{tabular}

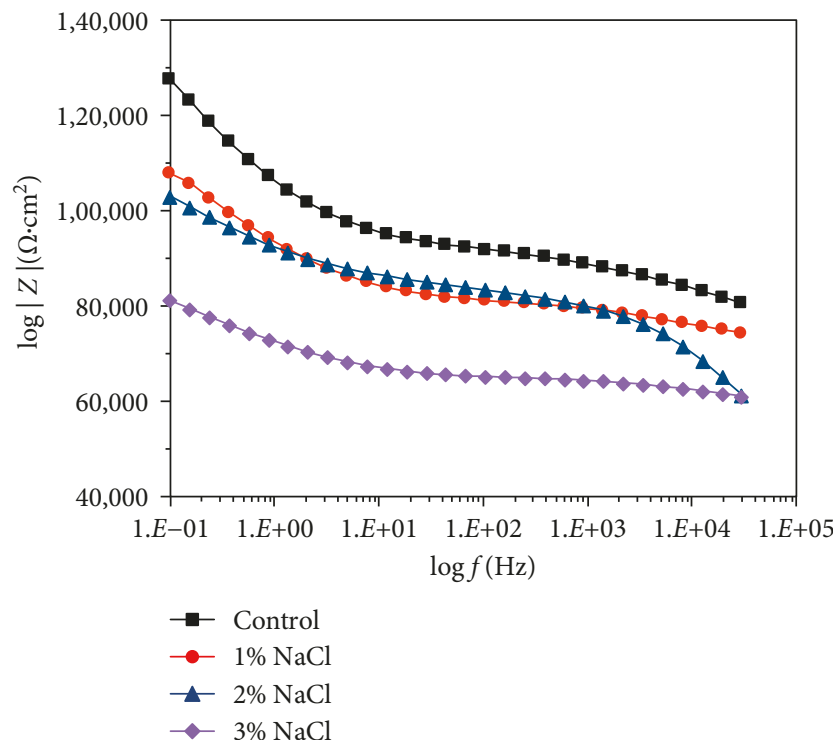

(a)

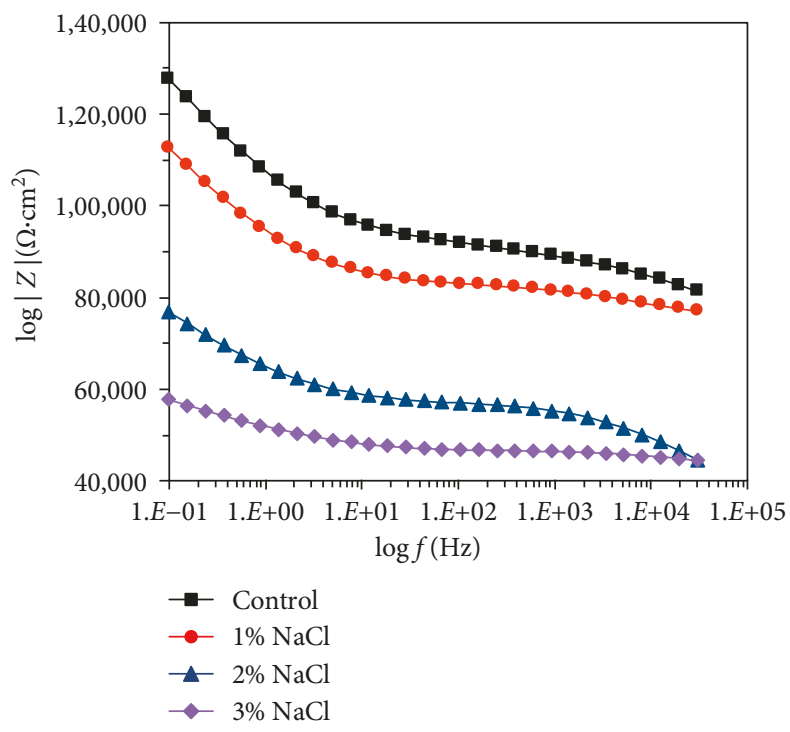

(b)

FIGURE 9: Impedance modulus curve for the rebar (a) and prestressed steel (b) in chloride-contaminated concrete.

the rebar after 30 days of exposure were $-291,-388$, and -458 in 1,2 , and $3 \%$ chloride levels, respectively. The $E_{\text {corr }}$ values for the rebar were $-424,-518$, and $-594 \mathrm{mV}$ indicating the severity of the corrosion in the prestressed steel when compared to the rebar. After 30 days of exposure, the corrosion current $\left(I_{\text {corr }}\right)$ and the corrosion rate of the 


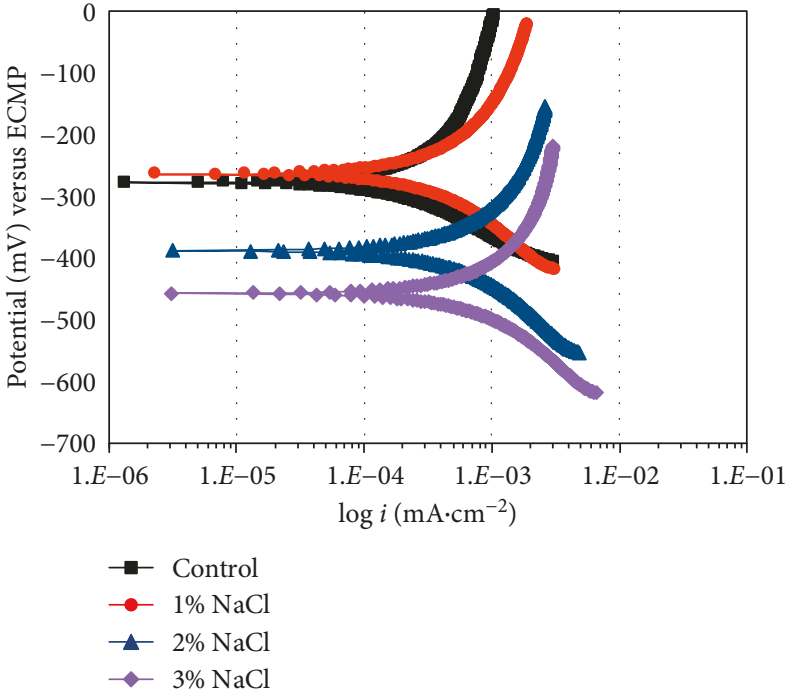

(a)

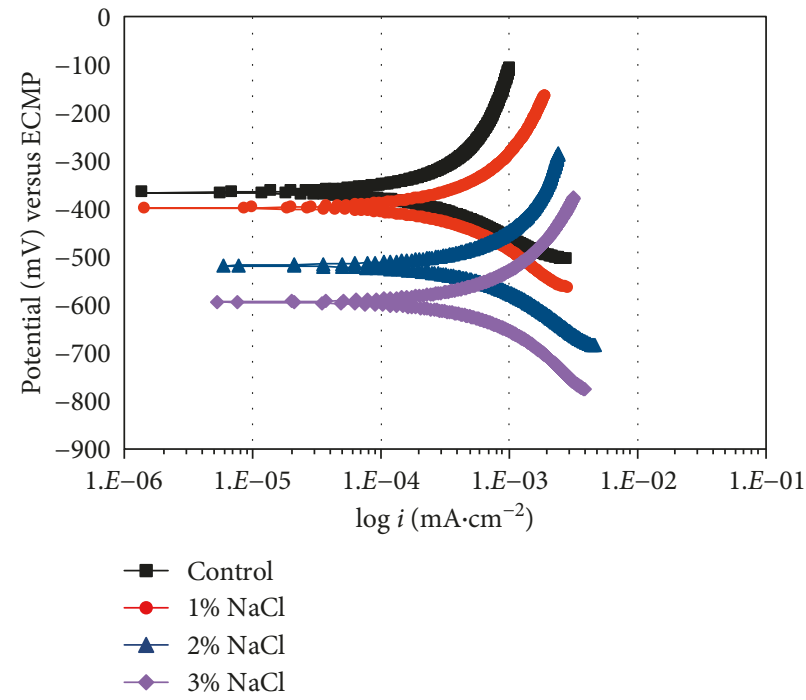

(b)

Figure 10: Potentiodynamic polarization curve for the rebar (a) and prestressed steel (b) in chloride-contaminated concrete.

TABLE 4: AC impedance parameters for the rebar and prestressed steel in chloride-contaminated concrete.

\begin{tabular}{|c|c|c|c|c|c|c|c|c|}
\hline \multirow[b]{3}{*}{ System } & \multicolumn{8}{|c|}{ AC impedance parameters } \\
\hline & \multicolumn{4}{|c|}{ Rebar } & \multicolumn{4}{|c|}{ Prestressed steel wire } \\
\hline & $\begin{array}{c}R_{\mathrm{ct}}\left(\Omega \cdot \mathrm{cm}^{2}\right) \times \\
10^{4}\end{array}$ & $\begin{array}{c}C_{\mathrm{dl}}\left(\mathrm{F} \cdot \mathrm{cm}^{-2}\right) \times \\
10^{-5}\end{array}$ & $\begin{array}{c}I_{\text {corr }} \\
\left(\mathrm{mA} \cdot \mathrm{cm}^{2}\right) \times \\
10^{-3}\end{array}$ & $\frac{\mathrm{CR}(\mathrm{mmpy}) \times}{10^{-2}}$ & $\begin{array}{c}R_{\mathrm{ct}}\left(\Omega \cdot \mathrm{cm}^{2}\right) \times \\
10^{4}\end{array}$ & $\begin{array}{c}C_{\mathrm{dl}}\left(\mathrm{F} \cdot \mathrm{cm}^{-2}\right) \times \\
10^{-5}\end{array}$ & $\begin{array}{c}I_{\text {corr }} \\
\left(\mathrm{mA} \cdot \mathrm{cm}^{2}\right) \times \\
10^{-3}\end{array}$ & $\begin{array}{c}\mathrm{CR} \\
\underset{10^{-2}}{(\mathrm{mmpy}) \times}\end{array}$ \\
\hline Control & 4.897 & 1.733 & 0.533 & 0.617 & 4.355 & 1.623 & 0.599 & 0.694 \\
\hline $\begin{array}{l}1 \% \\
\mathrm{NaCl}\end{array}$ & 4.010 & 2.225 & 0.651 & 0.754 & 3.766 & 2.088 & 0.692 & 0.803 \\
\hline $\begin{array}{l}2 \% \\
\mathrm{NaCl}\end{array}$ & 2.357 & 2.417 & 1.107 & 1.283 & 2.286 & 3.174 & 1.141 & 1.323 \\
\hline $\begin{array}{l}3 \% \\
\mathrm{NaCl}\end{array}$ & 2.131 & 2.618 & 1.224 & 1.419 & 1.441 & 5.125 & 1.810 & 2.098 \\
\hline
\end{tabular}

prestressed steel were found to be higher when compared to the rebar. The corrosion rate of the rebar was $0.721,1.167$, $1.524 \times 10^{-3}$ mmpy in 1,2 , and $3 \%$ chloride levels, respectively. The corrosion rate of the prestressed steel was $0.771,1.374,1.586 \times 10^{-3}$ mmpy in 1,2 , and $3 \%$ chloride levels, respectively. The stressed steel has $1.04,1.18$, and 1.04 times higher corrosion rate than the rebar at 1,2, and 3\% chloride levels, respectively. From the potentiodynamic polarization curve, it is observed that the stressed steel has corroded severely than the rebar.

From the abovementioned electrochemical studies, it is found that the shift in the corrosion rate was higher at $2 \%$ chloride level when compared to $1 \%$ and $3 \%$ chloride levels. This may be due to the fact that initially during the hydration, at $1 \%$ chloride levels, the chlorides combined with the cement to form a complex called the Friedel salt $[47,48]$, and it reduced the availability of free chloride ions. At $2 \%$ chloride, the complex formation was found to be lower, and the free chloride ions may be higher to cause more corrosion both in the case of the rebar and prestressed steel.
3.2. Flexure Test. Figure 11 shows the load versus displacement behavior of $0,1,2$, and $3 \%$ chloride-admixed prestressed concrete beams tested under two-point loading. Table 5 shows the initial and final crack load and the modulus of rupture for the various chloride-admixed concrete beams after 30 days of exposure. From Figure 10, it is found that the cracks appeared in the midspan. An additional increase in load under various stages resulted in the formation of additional cracks and widening of some earlier formed cracks. The cracks from the tension zone traversed up to the neutral axis, and cracking of the concrete took place at later stages. The failure of the specimen occurred due to the fast propagation of the cracks. From the load versus displacement curve, it is found that the maximum ultimate load for $0,1,2$, and $3 \%$ of the chloridecontaminated concretes is $120.6,98.5,90.6$, and $80.9 \mathrm{kN}$, respectively. From the results, it is observed that when compared to the control concrete, the chloridecontaminated concrete has reduced the load-carrying capacity of $18.3,24.9$, and $32.9 \%$ for 1,2 , and $3 \%$ chlorideadmixed concrete. The modulus of rupture was also found to 


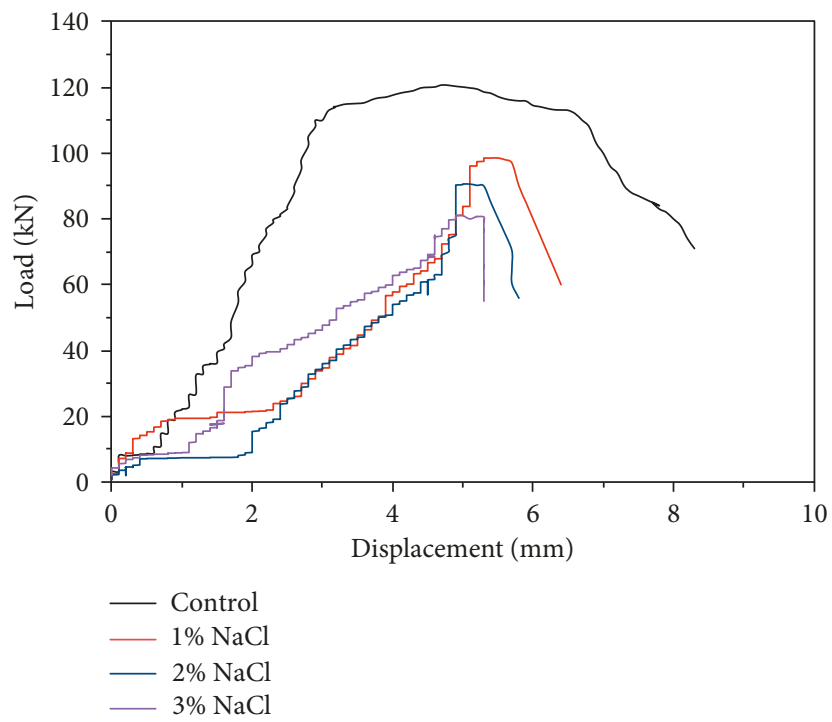

Figure 11: Load versus displacement behavior of corroded prestressed concrete beams after 30 days of exposure under various chloride levels.

TABle 5: Potentiodynamic polarization parameters for the rebar and prestressed steel in chloride-contaminated concrete.

\begin{tabular}{lcccccc}
\hline System & \multicolumn{2}{c}{ Potentiodynamic polarization parameters } \\
& $E_{\text {corr }}(\mathrm{mV})$ & $I_{\text {corr }}\left(\mathrm{mA} \cdot \mathrm{cm}^{2}\right) \times 10^{-4}$ & $\begin{array}{c}\text { Corrosion rate } \\
(\mathrm{mmpy}) \times 10^{-3}\end{array}$ & $E_{\text {corr }}(\mathrm{mV})$ & $I_{\text {corr }}\left(\mathrm{mA} \cdot \mathrm{cm}^{2}\right) \times 10^{-4}$ & $\begin{array}{c}\text { Corrosion rate } \\
\left(\mathrm{mmpy}^{2} \times 10^{-3}\right.\end{array}$ \\
\hline Control & -250 & 0.455 & 0.527 & -340 & 0.630 & 0.730 \\
$1 \% \mathrm{NaCl}$ & -291 & 0.622 & 0.721 & -424 & 0.648 & 0.771 \\
$2 \% \mathrm{NaCl}$ & -388 & 1.007 & 1.167 & -518 & 1.186 & 1.374 \\
$3 \% \mathrm{NaCl}$ & -458 & 1.315 & 1.524 & -594 & 1.374 & 1.586 \\
\hline
\end{tabular}

decrease with increase in the chloride concentration. The decrease in the modulus of rupture is due to the presence of chloride ions which caused the corrosion of reinforcement and prestressed steel, leading to the reduction in the loadcarrying capacity of the beam $[49,50]$.

\section{Conclusions}

(1) The flexural strength of the prestressed concrete beam was decreased by $32.9 \%$ as the chloride content was increased to $3 \%$.

(2) The corrosion rate of the prestressed steel is found to be higher than that of the rebar.

(3) The present investigation further demonstrates that the ECN measurement combined with other electrochemical techniques is used to study the corrosion process of the prestressing steel. The ECN results are in good agreement with those of the OCP and EIS measurements.

(4) The ECN clearly indicated the potential and current shift with chloride contents. The potential shifts observed were found to be $-190 \mathrm{mV}$ for $0 \% \mathrm{Cl}^{-}$and
$-510 \mathrm{mV}$ for $3 \% \mathrm{Cl}^{-}$in the stressed condition. These data showed 2.68 times shift for chloridecontaminated prestressed concrete beam.

(5) From the abovementioned experiments, it is found that the ECN clearly indicated the corrosion status of the chloride-contaminated and -uncontaminated prestressed steel and rebar.

\section{Conflicts of Interest}

The authors declare that there are no conflicts of interest in publishing this paper.

\section{Acknowledgments}

This research was supported by the Basic Science Research Program through the National Research Foundation of Korea (NRF) funded by the Ministry of Science, ICT and Future Planning (no. 2015R1A5A1037548). Velu Saraswathy thanks the Director, CECRI, and CSIR for the permission to pursue the fellowship at Hanyang University, Erica campus, Korea. 


\section{References}

[1] Post-Tensioning Institute, Post-Tensioning Manual, pp. 5-54, PTI, Phoenix, AZ, USA, 6th edition, 2006.

[2] T. Y. Lin and N. H. Burns, Design of Prestressed Concrete Structures, John Wiley \& Sons, New York, NY, USA, 3rd edition, 1981.

[3] R. F. Warner and K. A. Faulkes, Prestressed Concrete, pp. 1-13, Longman Cheshire, Melbourne, VIC, Australia, 2nd edition, 1988.

[4] A. S. El-Amoush and S. A. Al-Duheisat, "Cathodic polarization behavior of the structural steel wires under different prestressing conditions," Journal of Materials Research and Technology, 2017, in press.

[5] M. S. Darmawan and M. G. Stewart, "Spatial time-dependent reliability analysis of corroding pretensioned prestressed concrete bridge girders," Structural Safety, vol. 29, no. 1, pp. 16-31, 2007.

[6] M. S. Darmawan and M. G. Stewart, "Effect of pitting corrosion on capacity of prestressing wires," Magazine of Concrete Research, vol. 59, no. 2, pp. 131-139, 2007.

[7] P. Gardoni, R. G. Pillai, M. B. D. Hueste, K. Reinschmidt, and D. Trejo, "Probabilistic capacity models for corroding posttensioning strands calibrated using laboratory results," Journal of Engineering Mechanics, vol. 135, no. 9, pp. 906-916, 2009.

[8] R. G. Pillai, P. Gardoni, D. Trejo, M. B. D. Hueste, and K. F. Reinschmidt, "Probabilistic models for the tensile strength of corroding strands in post-tensioned segmental concrete bridges," Journal of Materials in Civil Engineering, vol. 22, no. 10, pp. 967-977, 2010.

[9] N. A. Vu, A. Castel, and R. François, "Effect of stress corrosion cracking on stress-strain response of steel wires used in prestressed concrete beams," Corrosion Science, vol. 51, no. 6, pp. 1453-1459, 2009.

[10] J. Woodtli and R. Kieselbach, "Damage due to hydrogen embrittlement and stress corrosion cracking," Engineering Failure Analysis, vol. 7, no. 6, pp. 427-450, 2000.

[11] J. Toribio, "The role of crack tip strain rate in hydrogen assisted cracking," Corrosion Science, vol. 39, no. 9, pp. 1687-1697, 1997.

[12] N. A. Vu, A. Castel, and R. François, "Response of posttensioned concrete beams with unbonded tendons including serviceability and ultimate state," Engineering Structure, vol. 32, no. 2, pp. 556-569, 2010.

[13] D. G. Cavell and P. Waldron, "A residual strength model for deteriorating post-tensioned concrete bridges," Computers \& Structures, vol. 79, no. 4, pp. 361-373, 2001.

[14] M. Grinfeld, "Stress corrosion cracking of an elastic plate," Acta Materialia, vol. 46, no. 2, pp. 631-636, 1998.

[15] A. Toshimitsu Yokobori Jr., Y. Chinda, T. Nemoto, K. Satoh, and T. Yamada, "The characteristics of hydrogen diffusion and concentration around a crack tip concerned with hydrogen embrittlement," Corrosion Science, vol. 44, no. 3, pp. 407-424, 2002.

[16] A. Turnbull, L. N. McCartney, and S. Zhou, "Modelling of the evolution of stress corrosion cracks from corrosion pits," Scripta Materialia, vol. 54, no. 4, pp. 575-578, 2006.

[17] F. Li, Y. Yuan, and C. Q. Li, "Corrosion propagation of prestressing steel strands in concrete subject to chloride attack," Construction and Building Materials, vol. 25, no. 10, pp. 3878-3885, 2011.
[18] A. Valiente, "Stress corrosion failure of large diameter pressure pipelines of prestressed concrete," Engineering Failure Analysis, vol. 8, no. 3, pp. 245-261, 2001.

[19] R. Helmerich and A. Zunkel, "Partial collapse of the Berlin Congress Hall on May 21st, 1980," Engineering Failure Analysis, vol. 43, pp. 107-119, 2014.

[20] S. Ramadan, L. Gaillet, C. Tessier, and H. Idrissi, "Detection of stress corrosion cracking of high-strength steel used in prestressed concrete structures by acoustic emission technique," Applied Surface Science, vol. 254, no. 8, pp. 2255-2261, 2008.

[21] R. W. Posten and J. P. Wouters, Durability of Precast Segmental Bridges, NCHRP Web Document No. 15, Project 20-7/Task 92, Transportation Research Board, National Research Council, Washington, DC, USA, 1998.

[22] M. S. Darmawan, "Pitting corrosion model for partial prestressed concrete (PC) structures in a chloride environment," Journal of Technology Science, vol. 20, no. 3, pp. 109-118, 2009.

[23] L. Dai, L. Wang, J. Zhang, and X. Zhang, "A global model for corrosion-induced cracking in prestressed concrete structures," Engineering Failure Analysis, vol. 62, pp. 263-275, 2016.

[24] W. Zhang, X. Liu, and X. Gu, "Fatigue behavior of corroded prestressed concrete beams," Construction and Buildings Materials, vol. 106, pp. 198-208, 2016.

[25] X. Zhang, L. Wang, J. Zhang, Y. Ma, and Y. Liu, "Flexural behavior of bonded post-tensioned concrete beams under strand corrosion," Nuclear Engineering and Design, vol. 313, pp. 414-424, 2017.

[26] K. A. Harries, "Structural testing of prestressed concrete girders from the Lake View Drive Bridge," Journal of Bridge Engineering, vol. 14, no. 2, pp. 78-92, 2009.

[27] M. Kiviste and J. Miljan, "Evaluation of residual flexural capacity of existing pre-cast pre-stressed concrete panels-a case study," Engineering Structure, vol. 32, no. 10, pp. 33773383, 2010.

[28] D. Coronelli, A. Castel, N. A. Vu, and R. François, "Corroded post-tensioned beams with bonded tendons and wire failure," Engineering Structure, vol. 31, no. 8, pp. 1687-1697, 2009.

[29] C. Q. Li, Y. Yang, and R. E. Melchers, "Prediction of reinforcement corrosion in concrete and its effects on concrete cracking and strength reduction," ACI Materials Journal, vol. 105, no. 1, pp. 3-10, 2008.

[30] A. A. Torres-Acosta and M. Martínez-Madrid, "Residual life of corroding reinforced concrete structures in marine environment," Journal of Materials in Civil Engineering, vol. 15, no. 4, pp. 344-353, 2003.

[31] H. Minh, H. Mutsuyoshi, and K. Niitani, "Influence of grouting condition on crack and load-carrying capacity of post-tensioned concrete beam due to chloride-induced corrosion," Construction and Building Materials, vol. 21, no. 7, pp. 1568-1575, 2007.

[32] H. Minh, H. Mutsuyoshi, H. Taniguchi, and K. Niitani, "Chloride-induced corrosion in insufficiently grouted posttensioned concrete beams," Journal of Materials in Civil Engineering, vol. 20, no. 1, pp. 85-91, 2008.

[33] A. Castel, D. Coronelli, N. A. Vu, and R. François, "Structural response of corroded, unbonded post-tensioned beams," Journal of Structural Engineering, vol. 137, no. 7, pp. 761-771, 2010.

[34] R. G. Pillai, D. Trejo, P. Gardoni, M. B. D. Hueste, and K. Reinschmidt, "Time-variant flexural reliability of posttensioned, segmental concrete bridges exposed to corrosive environments," Journal of Structural Engineering, vol. 140, no. 8, p. A4014018, 2014. 
[35] A. Torres-Acosta, S. Navarro-Gutierrez, and J. Terán-Guillén, "Residual flexure capacity of corroded reinforced concrete beams," Engineering Structure, vol. 29, no. 6, pp. 1145-1152, 2007.

[36] F. Li, Y. Qu, and J. Wang, "Bond life degradation of steel strand and concrete under combined corrosion and fatigue," Engineering Failure Analysis, vol. 80, no. 10, pp. 186-196, 2017.

[37] F. Li and Y. Yuan, "Effects of corrosion on bond behavior between steel strand and concrete," Construction and Building Materials, vol. 38, pp. 413-422, 2013.

[38] S. Muralidharan, T. H. Ha, J. H. Bae et al., "Electrochemical studies on the solid embeddable reference sensors for corrosion monitoring in concrete structure," Materials Letters, vol. 60, no. 5, pp. 651-655, 2006.

[39] K. Subbiah, S. Velu, S.-J. Kwon, H.-S. Lee, N. Rethinam, and D.-J. Park, "A novel in-situ corrosion monitoring electrode for reinforced concrete structures," Electrochimica Acta, 2017. in press.

[40] M. Aballe, F. J. Bethencourt, M. Botana, J. M. Marcos, and A. Sánchez, "Influence of the degree of polishing of alloy AA 5083 on its behavior against localized alkaline corrosion," Corrosion Science, vol. 46, no. 8, pp. 1909-1920, 2004.

[41] S. Girija, U. K. Mudali, V. R. Raju, R. K. Dayal, H. S. Khatak, and B. Raj, "Determination of corrosion types for AISI type 304L stainless steel using electrochemical noise method," Materials Science and Engineering A, vol. 407, no. 1-2, pp. 188-195, 2005.

[42] R. J. K. Wood, J. A. Wharton, A. J. Speyer, and K. S. Tan, "Investigation of erosion-corrosion processes using electrochemical noise measurements," Tribology International, vol. 35, no. 10, pp. 631-634, 2002.

[43] M. C. Deya, B. del Amo, E. Spinelli, and R. Romagnoli, "The assessment of a smart anticorrosive coating by the electrochemical noise technique," Progress Organic Coatings, vol. 76, no. 14 , pp. 525-532, 2013.

[44] H. W. Song and V. Saraswathy, "Corrosion monitoring of reinforced concrete structures-a review," International Journal of Electrochemical Science, vol. 2, pp. 1-28, 2007.

[45] B. Zhao, J. H. Li, R. G. Hu, R. G. Du, and C. J. Lin, "Study on the corrosion behavior of reinforcing steel in cement mortar by electrochemical noise measurements," Electrochimica Acta, vol. 52, no. 12, pp. 3976-3984, 2007.

[46] R. G. Duarte, A. S. Castela, R. Neves, L. Freire, and M. F. Montemor, "Corrosion behaviour of stainless steel rebars embedded in concrete: an electrochemical impedance spectroscopy study," Electrochimica Acta, vol. 124, pp. 218224, 2014.

[47] K. Thangavel, S. Muralidharan, V. Saraswathy, K. Y. Ann, and L. Balamurugan, "Relationship between alumina and chloride content on their physical and corrosion resistance properties of concrete," Arabian Journal for Science and Engineering, vol. 35, no. 28, pp. 27-38, 2009.

[48] S. P. Karthick, S. Muralidharan, V. Saraswathy, and S. J. Kwon, "Effect of different alkali salt additions on concrete durability property," Journal of Structural Integrity and Maintenance, vol. 1, no. 1, pp. 35-42, 2016.

[49] M. Moawad, H. EI-Karmoty, and A. EI Zanaty, "Behavior of corroded bonded fully prestressed and conventional concrete beams," HBRC Journal, 2016. in press.

[50] M. Moawad, A. Mahmoud, H. EI-Karmoty, and A. EI Zanaty, "Behavior of corroded bonded partially prestressed concrete beams," HBRC Journal, 2016. in press. 


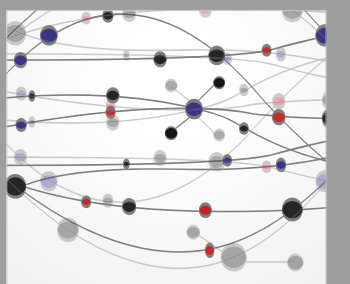

The Scientific World Journal
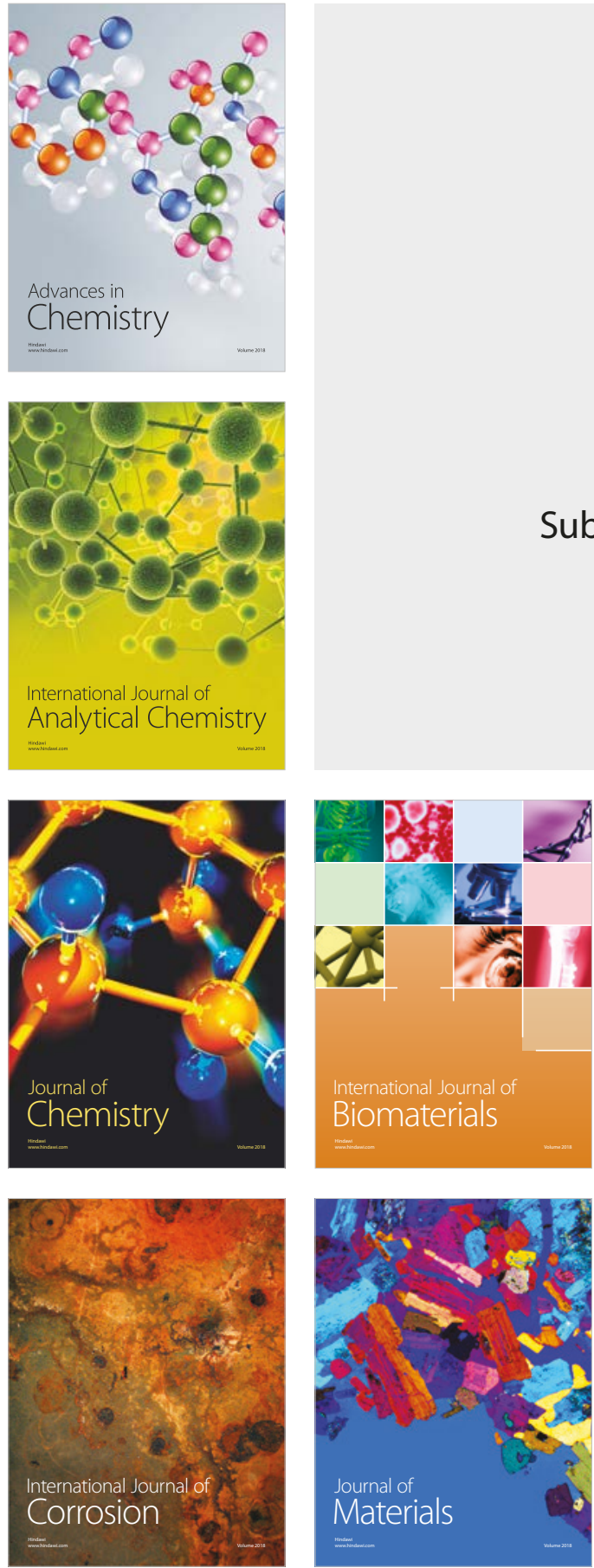

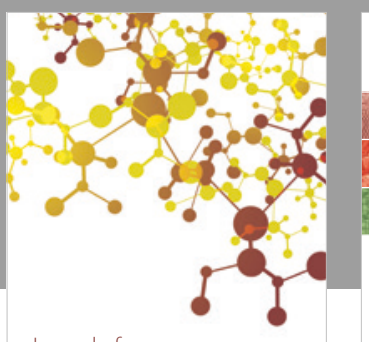

Journal of

Applied Chemistry
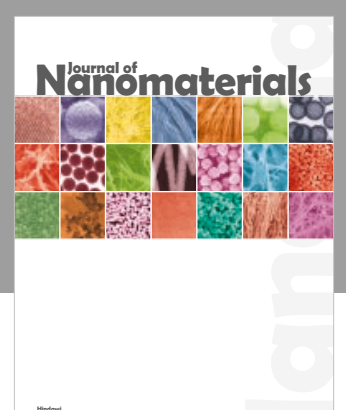

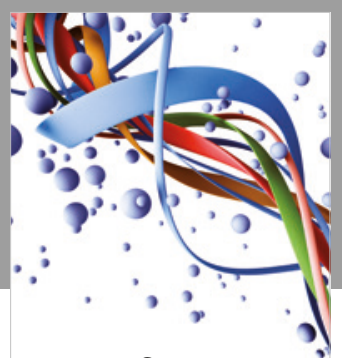

Scientifica

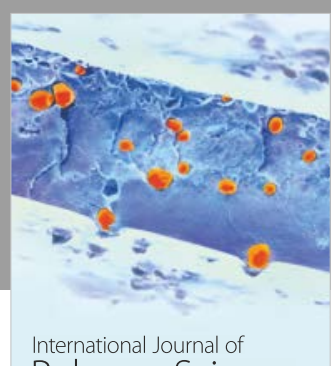

Polymer Science

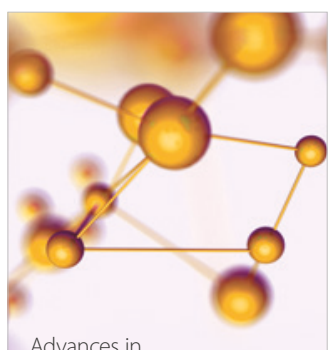

Physical Chemistry
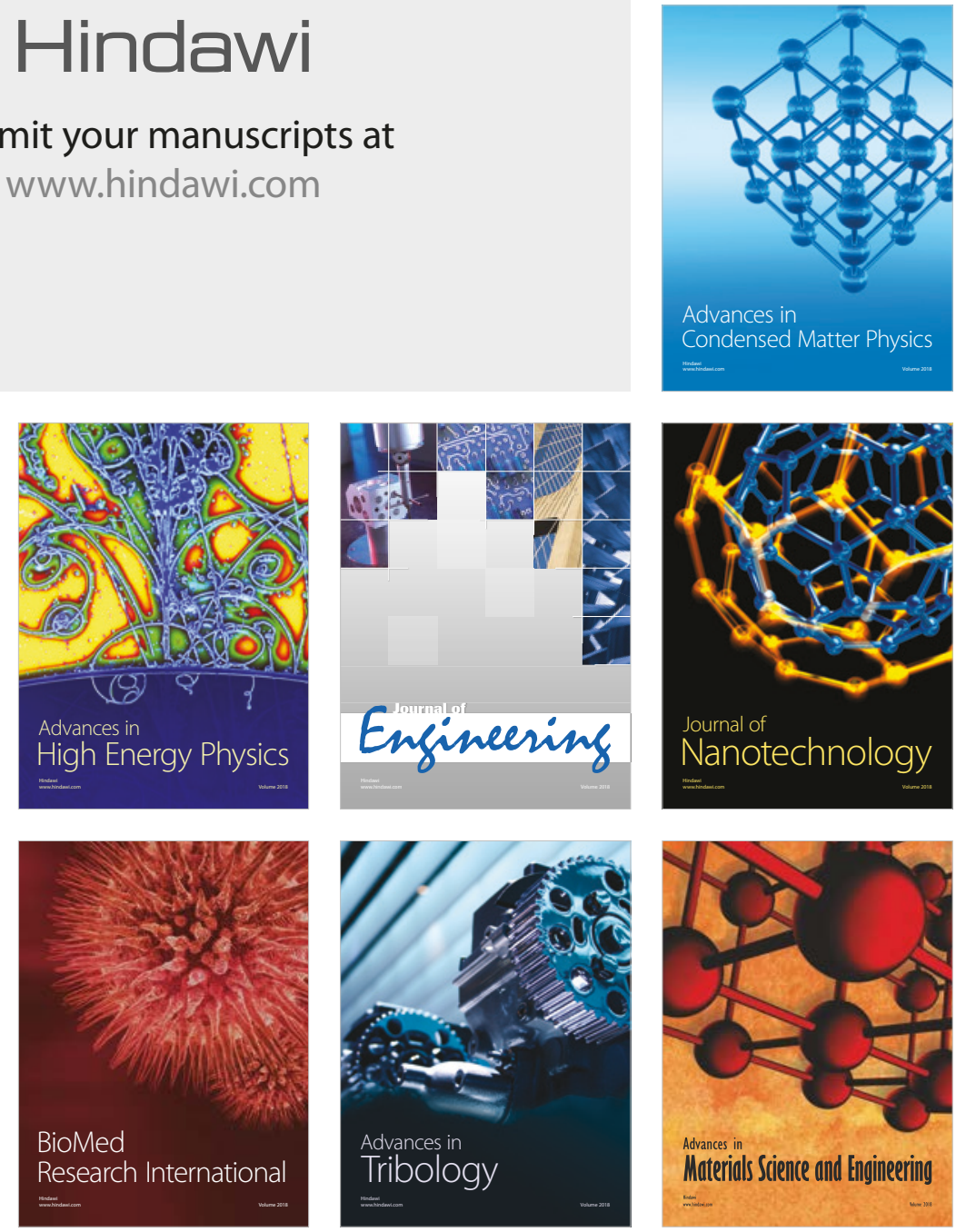